\title{
A STUDY ON STRESS TOLERANCE ABILITY OF TEACHER EDUCATORS
}

\begin{abstract}
The present study is designed to understand the stress tolerance ability of Teacher Educators. The sample consisted of 150 Teacher Educators, who were selected on the basis of descriptive and differential analysis, simple random techniques is used in the study. The variables included were stress tolerance ability. Data were collected from Jaipur district. The investigator has employed the research tool namely Stress Tolerance Ability Scale for Teachers has been constructed by Dr. Sareen (2008) for the present investigation. The results show that the stress scores have revealed that the Teacher Educators of Jaipur district have high stress tolerance ability.
\end{abstract}

Dr. Harsh Kumar

Principal, Poddar Management Training Institute

Vatika, Jaipur

Key words: Stress tolerance ability and Teachers.

\section{INTRODUCTION}

Stress tolerance is the ability to withstand adverse events and stressful situations without developing physical or emotional symptoms, by actively and positively coping with stress. This ability is based on

A capacity to choose courses of action for dealing with stress (being resourceful and effective, being able to come up with suitable methods, knowing what to do and how to do it);

An optimistic disposition toward new experiences and change in general, and toward your own ability to successfully overcome the specific problem at hand; and
A feeling that you can control or influence. Every individual has a set of 12 executive skills (self-restraint, working memory, emotion control, focus, task initiation, time management, planning / prioritization, organization, defining and achieving goals, flexibility, observation and stress tolerance). Each person has two or three that are their strongest and two or three that are their weakest, and they are not dramatically changeable for life.

\section{Need and Importance of the Study}

For the development of any institution, stress tolerance ability of employees is of prime importance. Particularly an educational institution cannot 
achieve its goals and objectives, the teacher who constitute one of the important components in teaching learning process are stressed with their occupation. The effectiveness of teaching and success of any educational system depend upon the active involvement of teachers. A teacher is stressed with his work; he/she may not deliver his duties effectively. The performance of teaching of any educational system depends upon the stress tolerance ability of teachers. Stress is person specific. What is stressful to one person is not necessarily stressful to another. There are as many responses to stressful situation as there are individuals and two people in the same stressful situation may well respond quite differently from each others. Colleges too need to adopt a considered approach to the management of staff stress. Stress in teaching is inherent in the way; teachers are expected to work in many colleges today. The stress of teachers negatively affected the students. So the present study is very important for stress reduction of teacher.

\section{Statement of the Problem}

Stress tolerance ability is of vital importance and it plays an important role for the happiness, devotion of teachers to their work, for the realization of goals of the organization. Hence an attempt has been made in the study to consider "A STUDY

ON STRESS TOLERANCE ABILITY OF TEACHER EDUCATORS" METHOD OF THE STUDY

Since the study deals with the present conditions, normative survey method is used.

\section{Tool of the Study}

Stress tolerance ability developed and standardized by the Dr. Sareen (2008) questionnaire is used in the present investigation.

\section{Sample}

With the help of random sampling techniques, 150 Teacher Educators of Jaipur district in Rajasthan is selected for the study.

\section{Design of the Study}

In educational research there are different methods in doing research. The most commonly used approach is normative research method. The same method has used in this research.

\section{Objectives of the Study}

1. To find out the stress tolerance ability of Teacher Educators.

2. To find out is there any significant difference between Teacher Educators those who are having below 8 years of teaching experience and above 8 years of 
teaching experience in respect of stress tolerance ability.

\section{Hypotheses of the Study}

1. The Teacher Educators of Jaipur district has high stress tolerance ability.

2. There is no significant difference between Teacher Educators those who are having below 8 years of teaching experience and above 8 years of teaching experience in respect of stress tolerance ability.

\section{RESULTS}

Analysis of Stress tolerance ability of Teacher Educators

In order to understand the stress tolerance ability of Teacher Educators, mean and standard deviation have been calculated. The values of mean and standard deviation have been represented in table-1. It shows that the mean value is 158.02 and standard deviation value is 14.02 . The author of the scale has indicated that the scores between 46-122 is considered as low stress tolerance ability, the scores between 123-155 is considered as moderate stress tolerance ability and the scores between 156-230 is considered as high stress tolerance ability. Here the calculated value 158.02 is falling in the line of high stress tolerance ability. Now it is concluded that the Teacher Educators of
Jaipur district have high stress tolerance ability.

Table - 1

Analysis of mean value scores of teacher educators those who are having below 8 years of experience and above 8 years of experience in respect of stress tolerance ability stress tolerance ability of college teachers

\begin{tabular}{|l|l|l|}
\hline $\begin{array}{l}\text { Total } \\
\text { Population }\end{array}$ & $\begin{array}{l}\text { Mean } \\
\text { value }\end{array}$ & $\begin{array}{l}\text { Standard } \\
\text { Deviation }\end{array}$ \\
\hline 150 & 158.02 & 14.02 \\
\hline
\end{tabular}

In order to find out whether is any significant difference between Teacher Educators those who are having below 8 years of experience and above 8 years of experience in respect of stress tolerance ability, t-value is calculated. The critical ration is found to be 1.58 . The ' $t$ ' value 1.58 is lower than the table value at 0.05 level. Hence the null hypothesis is accepted at 0.05 level. It concludes that there is no significant difference between Teacher Educators those who are having below 8 years of experience and above 8 years of experience in respect of stress tolerance ability. The't' value is represented in table 2 . 
Table - 2

Table shows the t-value of Teacher Educators those who are having below 8 years of experience and above 8 years of experience in respect of stress tolerance ability.

\begin{tabular}{|l|l|l|l|l|l|}
\hline $\begin{array}{l}\text { Experie } \\
\text { nce }\end{array}$ & $\mathrm{N}$ & Mean & S.D. & $\begin{array}{l}\text { t- } \\
\text { value }\end{array}$ & $\begin{array}{l}\text { Level of } \\
\text { significance }\end{array}$ \\
\hline $\begin{array}{l}\text { Below } 8 \\
\text { years }\end{array}$ & 68 & 160.91 & 14.39 & 1.58 & $\begin{array}{l}\text { No } \\
\text { Significant }\end{array}$ \\
\hline $\begin{array}{l}\text { Above } \\
8 \text { years }\end{array}$ & 82 & $\begin{array}{l}157.8 \\
4\end{array}$ & 12.43 & & . \\
\hline
\end{tabular}

\section{CONCLUSION}

The present investigation has fielded many interesting result which bound to add to the volume of knowledge already present in the field of investigation.

\section{BIBLIOGRAPHY}

i. Aggarwal, (1986). Statistical method Concepts application and computation. Sterling Publishers Pvt. Ltd., New Delhi. ii. Bouserie, R. (1994). Sources and levels of stress in relation to locus of control and self-esteem in university students. Educational Psychology, 14 (3), 323330.

iii. Cristina Calderan, (2012), College students' levels of social integration in the campus community affects their feelings of stress and depression, American Psychologist, 46, 93-102.

iv. DeAnda, D. (1997). A study of stress, stressors and coping strategies among middle school adolescents. Social work in Education. 19,87-98.

v. DuBois, D., Felner, R., Brand, S., Adan, A., \& Evans, E. (1992), A prospective study of life stress, social support and adaptation in early adolescence. Child Development, 63,542-557. 